\title{
Accomplishing authentic writing tasks: Ventures into academic publication by Ecuadorian EFL teachers
}

\author{
$\operatorname{Agnes~Orosz~}^{1^{*}}$, Marcela Carrasco², Daniela Jaramillo ${ }^{3}$, and Erzsébet Békés ${ }^{4}$ \\ ${ }^{1}$ Department of English, Faculty of Education, Universidad Nacional de Educación, Chuquipata, Azogues, \\ Cañar, Ecuador \\ ${ }^{2,3}$ Department of Professional Education and Teacher Training, Universidad Católica de Cuenca, Av. Americas \& \\ Humboldt, Cuenca, Ecuador \\ ${ }^{4}$ CETAP Educational Center, Chilcapamba, Cuenca, Azuay, Ecuador
}

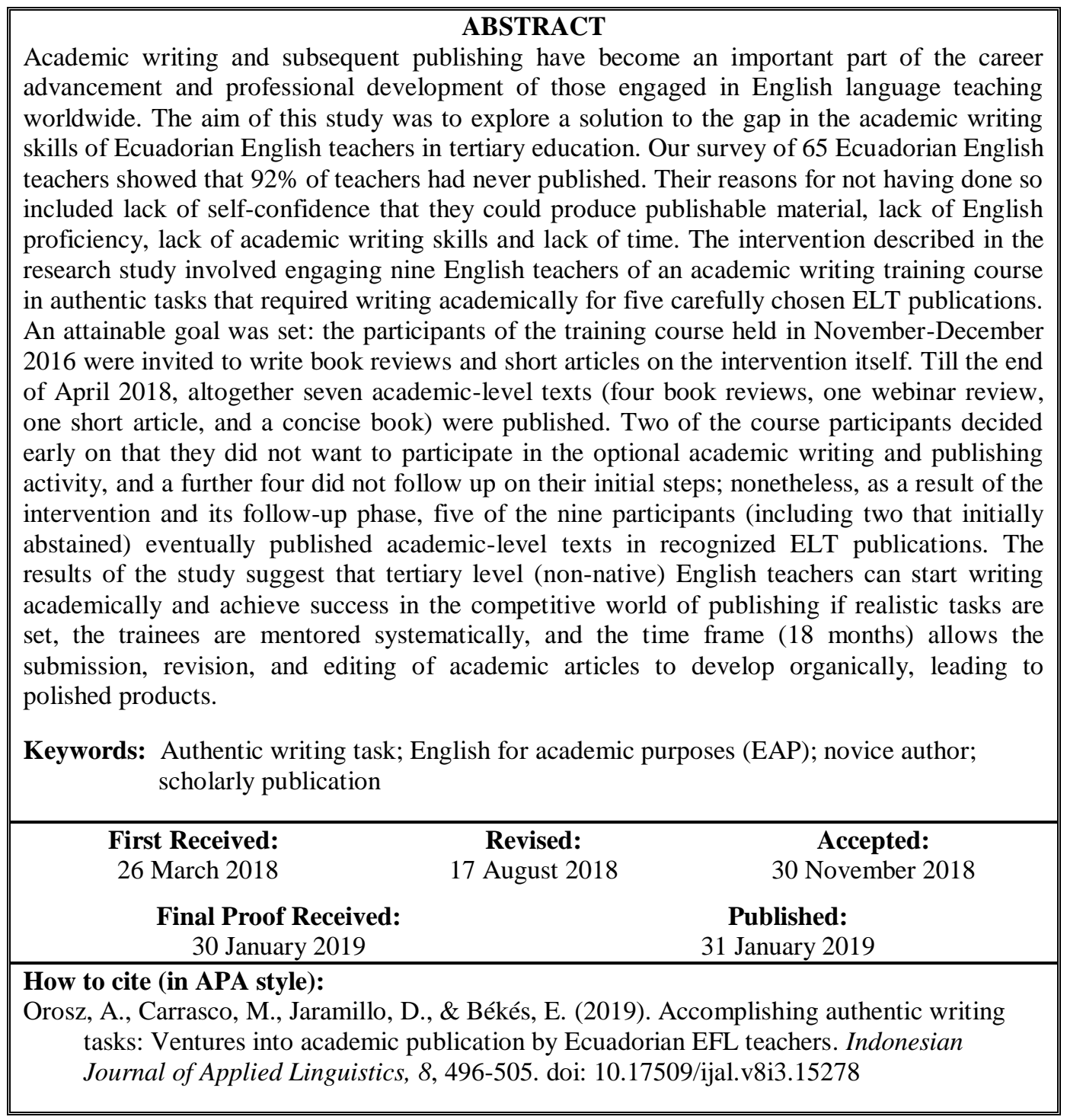

\section{INTRODUCTION}

Writing academically and publishing academic-level texts in English is a serious challenge for English instructors working at tertiary level in Ecuador.
University English professors have varying levels of academic writing competence; most of them are not obliged to write in English on a regular basis, and their extended BA essay or MA thesis might have been their

\footnotetext{
* Corresponding Author

Email: agnes.orosz@unae.edu.ec
} 
first and last piece of academic writing. The reasons for not having the required level of academic writing proficiency are manifold, but one explanation is that English instructors in Ecuador lack the necessary research skills and do not usually go through the apprenticeship process that would allow them to familiarize themselves with how they can become more polished writers by following the explicit and implicit conventions of academic writing.

In December 2016, the Catholic University of Cuenca, Ecuador, launched three new Master's programmes and prior to the start of the courses, the university's administration commissioned the newly established Academic Language Centre to set up a training course for nine English teachers, who had been selected to deliver academic writing courses to the MA postgraduates. One of the co-authors of the present article was contracted to deliver the training sessions. She decided to use the occasion as an opportunity to conduct a piece of action research by identifying the problem of insufficient academic writing experience, setting an appropriate task and reflecting on the outcomes of the process.

Consequently, the present research study involved designing and carrying out an intervention aimed at improving the academic writing skills of tertiary level English teachers and facilitating the creation of publishable scholarly works.

The main rationale behind the intervention was that if the teachers' task was to facilitate their postgraduate students' academic writing in English, it would be instructive if they went through the experience of writing at academic level and attempted to publish their writing. In this manner, the project employed the principle of 'learning by doing', which implied that the participants of the research project were expected to accomplish academic writing tasks and make a reasonable effort to publish. The full cycle meant that the teachers made an attempt to write academically, pursued opportunities to publish, and then reflected on both the experience and the outcomes of their academic writing.

\section{Authentic writing tasks in L1 and L2}

Authenticity in language teaching is a multi-layered concept. For the purposes of the present study, we follow Tomlinson and Masuhara's definition stating that authentic materials are "designed not to transmit declarative knowledge about the target language but rather to provide an experience of the language in use" (as cited in Pinner, 2016, p. 76). In our case, this implied that the participants of the teacher training course (on how to teach academic writing) were not given presentations on academic writing, but were encouraged to start writing academically; furthermore, the experience did not remain within the classroom walls, because the written texts had to survive the test of fire, namely, they had to be submitted and then either be accepted or rejected by the editors of reputable ELT publications.
While designing the authentic writing activity, which started by looking for publishing outlets that would accept texts like book reviews from novice authors, it became apparent that even though there is a wealth of material (both theoretical and practical) on authentic writing tasks in L1 (Lidvall, 2008; Lindblom, 2015), a lot less has been written on how authentic writing tasks may be set up in L2, and especially in an English as a foreign language (EFL) context (Ozverir, Herrington, \& Osam, 2016). This is not surprising, since authentic writing activities imply the existence of a real audience and a real message, neither of which is the usual setting in EFL. Furthermore, there appears to be a dearth of studies on how non-native English speaker teachers in an EFL setting may undertake academic writing activities for genuine, communicative purposes (e.g., for publishing).

How can authenticity be applied to writing tasks? To clarify the nature of an authentic writing task, Morrow's definition seems well-suited: "An authentic text is a stretch of real language, produced by a real speaker or writer for a real audience and designed to convey a real message of some sort" (as cited in Gilmore, 2007, p. 98). One could say that the word 'real' would need to be scrutinized further, but insofar as the present academic writing project was accomplished by real writers, whose texts were acknowledged by a real audience, while also carrying a real message, the description was deemed appropriate.

Therefore, as regards authentic writing activities, the criteria for native English speakers and for those who use English as an additional language are similar, since they posit a real writer, a real message and a real audience. Calkins says that there needs to be "a real, human reason to write" (as cited in Lidvall, 2008, p. 5), and the end result should be an accomplished product for an audience 'out there'.

As has already been mentioned, such tasks are not easy to design in English as a second language (ESL) context and are even more complicated to set up in an EFL context, namely, in situations where immersion is limited or non-existent. One attempt to do so is described by Ozverir et al. (2016), who used an elearning environment to promote 'authentic learning': the class taught at the English Preparatory School within a Cyprus university was set up to function as the editorial board of the so-called City Newsletter for a sixweek period (2016, p. 487). During the task-based activity, the teacher acted as the editor of the newsletter, while the learners served as journalists, who had to research a problem of social significance. Authenticity, from the point of view of the setup, necessarily remained relative: the task required the teacher and the students to take on an "authentic role", possibly a contradiction in terms. However, the social problems (drunk driving, water conservation) tackled by the student journalists were real, and so was the audience, namely, the whole student body of the campus, academic staff and the students' relatives. 
English for Academic Purposes and English for Professional Academic Purposes

According to Gillett (2011), English for Academic Purposes "refers to the language and associated practices that people need in order to undertake study or work in English medium higher education" (para. 1). EAP comes under the heading of English for Specific Purposes, where the teaching content is very closely matched to the learners' needs, namely, success in their academic careers. Gillett makes a further fine distinction between English for General Academic Purposes (EGAP) and English for Specific Academic Purposes (ESAP). However, for our purposes, Hyland's (2009) term - English for Professional Academic Purposes (EPAP) - seems better suited, because the target clientele of EPAP is academics (both native and nonnative) who write for scholarly publication, and this profile is the same as that of the participants who were involved in our academic writing activity.

Hyland's work has been of special importance for the academic writing and publication project presented here. His article (2009) on how English has become the language of international scholarship and how publishing in peer-reviewed journals is now a "prerequisite for tenure, promotion and career advancement" (p. 83), is an accurate description of the situation in which teachers find themselves at Ecuadorian universities.

\section{Global publishing and linguistic (dis)advantage}

Another article of Hyland's (2016) titled Academic publishing and the myth of linguistic injustice is especially pertinent, because attitude surveys show that authors for whom English is an additional language "often believe that editors and referees are prejudiced against them" (p. 59). Hyland stresses that while a certain level of proficiency is necessarily required, and this might be an added burden for non-native speaker authors, the fact of the matter is that English as an Additional Language (EAL) scholars might be at an advantage. He contends that the reason for their success at becoming 'academically bilingual' may be rooted in their exposure to EAP courses and years of apprenticeship in academic writing. In Hyland's view (p. 61), the native / non-native divide in academia is unhelpful: low acceptance and high rejection rates may have to do with the fact that EAL scholars often work in relative isolation and lack up-to-date technologies or sufficient funds to carry out research (p. 63).

As Bourdieu aptly points out, no one speaks (or writes) academic English as a first language (Bourdieu \& Passeron, 1994, p. 8.). Therefore, it can be assumed that native speakers also have to learn the discourse conventions of the genre. However, Békés and Carrasco (2017) suggest that what is known as the native speaker advantage is, in fact, brought about not so much by being born and educated in a country where English is used as a mother tongue, but by the fact that native speakers are exposed to a massive amount of meaningful, contextualized input (pp. 14-15). It would then follow that the language acquisition process, coupled with the kind of writing instruction that characterizes education in Kachru's (1985) inner circle (UK, US, Australia, New Zealand, Ireland and Anglophone Canada), does bring about a gap that nonnative scholars may find difficult to close.

\section{Examples of previous research}

Buckingham's (2008) research study emphasises both the challenges faced and the competitive advantage gained in the case of non-native academics. She used personal interviews to investigate how a group of 13 Turkish scholars developed their discipline-specific academic writing skills in English. She concludes that "the acquisition of scholarly writing expertise was an extended process of exploration of genre conventions, with a strong component of largely self-directed analysis of linguistic and organizational norms" (p. 1). All interviewees admitted that writing in English entailed a number of difficulties. However, some of the scholars mentioned that it was difficult for them to write academically in L1 (Turkish), which would seem to support Hyland's (2016) proposition, since these scholars' academic career involved a large amount of reading and a fair amount of writing in English and, as a result, they have become more skilled 'apprentices' than novice native speaker authors with less experience in academic writing.

\section{Support for novice scholars}

Swales contends that rather than the native/non-native divide, researchers and scholars should be categorized as “experienced or 'senior' researchers/scholars and less experienced or 'junior' ones" (as cited in Hyland, 2016, p. 63). This approach assumes that apprenticeship, or learning by doing, can be a powerful tool, and all the EPAP activities that Hyland (2009) describes, such as drawing up a list of journals in the scholars' relevant area, finding the right niche, taking note of a journal's publishing requirements (submission guidelines), and reflecting on successful strategies, may prove to be highly effective both for native and non-native authors (pp. 91-95).

The first steps in academic publication start after carrying out a well-designed research project and going through the elaborate process of writing it up. Renandya (2014) describes the daunting task of choosing the right international journal for one's research paper. His practical guidelines advise novice writers on the types of journals available in TESOL and draw attention to the most well-known and prestigious ones. He looks at rejection rates, and describes the review process and the relevant criteria that determine the quality of a journal, including being registered with internationally recognized indexing organizations. Renandya's tips are both helpful and sensible. Here is No. 6: "If you feel that you are not ready yet to write a full paper for a journal, you can try your hand at writing a book review" (Tips for novice writers section). 
That is the advice that the authors involved in this writing project followed; they started with book reviews, continued with short articles in journals whose acceptance rate seemed reasonable, and finally, two authors, Békés and Carrasco (2017) ventured out into what Renandya calls "the jungle out there". That is how their concise book on non-native English speaker teachers' identity was born.

\section{METHOD}

\section{Research objectives}

The purpose of the present study was to: a) establish how tertiary level Ecuadorian teachers can be supported in their authentic, publishing-driven academic writing; b) verify the success/failure rate of a publication project that involved approaching editors and publishers with pieces of accomplished texts whose genre fitted the purpose and the profile of the publishing organisation chosen.

\section{Instruments}

Quantitative data were collected using an online survey about the academic writing and publishing activities of 65 Ecuadorian English teachers. The aim was to confirm to what extent these instructors needed support with their academic writing skills. The respondents were also asked about their academic writing practices and their success in publishing.

For the gathering of qualitative data, a quasiexperimental-qualitative design was applied using a convenience sample of the nine teachers who had been selected to participate owing to their proven track record, experience and availability. The intervention, which aimed at encouraging as well as supporting the nine participants in their academic writing endeavours, was carried out within the framework of a teacher training course that was delivered in late 2016, preparing these instructors to teach academic writing skills in English to incoming Master's students at the Catholic University of Cuenca, Ecuador. The data regarding the nine participants were collected in two stages: during the training course and in the follow-up period; the latter can be divided into three phases based on the publishing outcomes in each stage.

In the following section, we examine the findings of the research, including an evaluation of the publishing project and the discussion of the merits and challenges of an approach that required the participants to make the leap from lecturing on academic writing to publishing articles in recognized international ELT publications.

\section{FINDINGS AND DISCUSSION \\ Online survey}

In order to obtain an overview of the general publishing experience of Ecuadorian ELT teachers, we invited teachers who belonged to an online group called "Ecuadorian English Teachers" to respond to a short online survey about their publishing experience. Sixtyfive teachers responded to the survey; $75 \%$ of them were female, $43 \%$ were between 31 and 40 years old, a quarter were between 21 and 30 years old, a quarter between 41 and 50, and the rest were 50+. The respondents had been teaching English for between 1 to 25 years with an average of 8 years' of teaching experience. Thirty percent of the respondents had a Master's, 63\% had a Bachelor's degree, and the rest had no university qualification.

\section{Summary of the results}

The results showed that although $61 \%$ of respondents had engaged in some sort of academic writing during their academic or professional careers, very few had actually published. Forty-one percent had written abstracts in English, 35\% had written their Bachelor's degree thesis in English, 18\% had written their Master's degree thesis in English and $18 \%$ had written articles in English.

However, what was striking was that only $8 \%$ of teachers, which equates to five respondents, had published anything they had written. The types of writing that were published were articles and abstracts, with an average of 1.2 pieces of text per author published. Noticeably, only two out of the six total published pieces of academic writing appeared in journals; the rest were published in newsletters or internal university publications. This means that the combined output of 65 Ecuadorian English teachers was only 2 pieces of academic writing that had reached the status of being published in a journal. The authors of these pieces were both females holding Master's degrees; both of them had over 15 years' teaching experience.

The $92 \%$ of the respondents who had never published, cited various reasons for not having done so. The most common reasons mentioned, in order of occurrence, were: lack of information about where to publish, lack of self-confidence that they can write publishable material, lack of academic writing skills, lack of time to carry out the research required for academic publishing and lack of time to write, as well as lack of general language proficiency.

\section{Conclusions drawn from online survey}

These results confirm that English teachers in Ecuador do indeed need support and mentoring in their academic writing activities. Specific areas to target are giving information about where to publish, providing training in academic writing skills in order to raise teachers' self-confidence in their own abilities, and encouraging teachers to make time for research and publishing.

\section{The publishing project}

Apart from the data gathered using the online survey, it was important to review the professional profiles of the teachers who participated in the academic writing training sessions and, consequently, became part of the publishing drive. In order to establish a "benchmark", 
Table 1 presents the nine participants' major professional details including their academic/literary output in English at the start of the course.

Although the authentic academic writing activity was one of the main tasks of the training course, other EAP topics were also included; for example, conducting a needs analysis (Gillett, 2011, Target Needs Analysis section, para. 1), recognizing Spanish-English cognates in academic vocabulary, analysing abstracts and summaries, and looking at rhetorical focus.

\section{Stages of the publishing project}

The academic writing activity started in the first session: all nine teachers were requested to approach editors and offer to write book reviews. The trainer was keen on setting a realistic, achievable task: with the 'attainable goal' principle in mind, the list of genres and the journals to be contacted were boiled down to the following: book reviews and short articles offered to the bi-monthly journal, Voices (IATEFL); the journal published by the English for Specific Purposes Special Interest Group (ESPSIG, IATEFL); the newsletter of the Teacher Training and Education Special Interest Group
(TTEd SIG, IATEFL); EL Gazette and the online EFL Magazine. It was important to highlight these publishing opportunities because the majority of English teachers in Ecuador lack information on where and how to publish (see survey results).

The trainer explained that the genre that the participants were working on was an 'unsolicited offer'. By way of scaffolding, she presented her own biodata and distributed a copy of her own book review (Békés, 2016). Next, the teachers wrote their own biodata and peer reviewed each other's details. During the week that followed, participants contacted the suggested journals and swiftly started receiving answers from the editors; even though the replies were non-committal, these were authentic exchanges, since the editors replied as they would have to any other unsolicited offer, i.e., meaningfully and informatively, and not 'pedagogically'. It is worth mentioning that two participants decided right at the outset that they had no time to approach publishers; one of the two, in fact, was going to write a speaker proposal for IATEFL's 2017 International Conference in Glasgow instead.

Table 1. Professional profile of participants and their academic/literary output in English

\begin{tabular}{|c|c|c|c|c|c|c|}
\hline No. & Gender & Highest qualification & $\begin{array}{l}\text { Teaching Experience } \\
\text { (Years) }\end{array}$ & Output in English & $\begin{array}{l}\text { Published } \\
\text { work }\end{array}$ & $\begin{array}{c}\text { First } \\
\text { Language }\end{array}$ \\
\hline 1. & $\mathrm{~F}$ & MA in Applied Linguistics & 10 & MA thesis & 0 & Spanish \\
\hline 2. & M & MA in Philosophy & 6 & MA thesis & 0 & German \\
\hline 3. & $\mathrm{~F}$ & $\begin{array}{l}\text { BA in English Language } \\
\text { \& Literature }\end{array}$ & 12 & BA essay, poetry & 0 & Spanish \\
\hline 4. & $\mathrm{~F}$ & MA in TESOL & 22 & MA thesis & 0 & Spanish \\
\hline 5. & M & $\begin{array}{l}\text { BA in Teaching English } \\
\text { TEFL Diploma }\end{array}$ & 9 & BA and Diploma essays & 0 & English \\
\hline 6. & $\mathrm{~F}$ & $\begin{array}{l}\text { BSc in Med. Lab. Tech. } \\
\text { TEFL Diploma }\end{array}$ & 14 & BSc and Diploma essays & 0 & English \\
\hline 7. & $\mathrm{~F}$ & MA in Applied Linguistics & 10 & MA thesis & 0 & Spanish \\
\hline 8. & $\mathrm{~F}$ & $\begin{array}{l}\text { MA in Applied Linguistics } \\
\text { CELTA }\end{array}$ & 13 & MA thesis, CELTA essays & 0 & Spanish \\
\hline 9. & $\mathrm{~F}$ & $\begin{array}{l}\text { MA in English Language } \\
\text { \& Literature }\end{array}$ & 40 & MA thesis & 0 & Spanish \\
\hline
\end{tabular}

In Session 2 and 3, the publishing opportunities were further refined. Participants looked at the options offered: one editor (Voices) replied that they would be in touch when they had a book to review, namely, a volume that was relevant to the areas of interest as given by the participants. Several editors said that they were happy to consider titles that the reviewers themselves wanted to write about (ESPSIG, EFL Magazine). Session 4 was dedicated to reflection and feedback on the course, with a short questionnaire specifically asking about the publishing effort. Table 2 summarizes the feedback on the authentic writing activity.

Evaluation of the authentic academic writing component of the course

Two participants opted out of the activity. The reason for this was that one of them claimed he did not have time for this non-obligatory task, while the other was supposed to be working on another piece of academic text (an IATEFL speaker proposal). In the end, the proposal was not submitted but this participant eventually contributed to the collaborative book review on the academic writing book that the teachers were going to use for their course with postgraduate students. The remaining seven participants were, by and large, satisfied with the course; the average level of interest was 4.28 points (out of 5). Five participants liked the activity unreservedly, describing it as "exciting", "stimulating" and "gratifying"; three of them eventually published. Two participants had their nagging doubts about the exercise; one of them has not published, but a book review by the other eventually materialized (Matute, 2018). 
Table 2. Feedback on the writing activity at the end of the course

\begin{tabular}{|c|c|c|c|c|}
\hline No & $\begin{array}{l}\text { Level of interest in } \\
\text { the activity }(1-5)\end{array}$ & Feelings about the academic writing & Notes & $\begin{array}{c}\text { Final outcome } \\
\text { P=Published } \\
\text { NP=Not published }\end{array}$ \\
\hline 1 & 3 & Worried, unsure about the task, but overall useful & & $\mathrm{P}$ \\
\hline 2 & 5 & Enjoyed, "excellent idea" & & NP \\
\hline 3 & 2 & Difficult, but good & & NP \\
\hline 4 & 5 & Liked it, enjoyed the activity & $\begin{array}{l}\text { Trainer facilitated, } \\
\text { EL Gazette book review }\end{array}$ & $\mathrm{P}$ \\
\hline 5 & N/A & & PP "too busy" & NP \\
\hline 6 & 5 & Exciting, engaging & & $\mathrm{NP}$ \\
\hline 7 & N/A & & PP exempted & $\mathrm{P}$ \\
\hline 8 & 5 & Stimulating, enjoyable & & $\mathrm{P}$ \\
\hline 9 & 5 & Engaging, gratifying & & $P$ \\
\hline
\end{tabular}

Source: Authors' data (gathered at the end of the course (feedback forms and interviews)

Note. $\mathrm{PP}=$ participant

The results seem to underline the importance of the affective factors that are at play when starting out in scholarly publication. In fact, the results of the online survey showed that one-third of respondents felt that the most important factor holding them back from publishing was lack of self-confidence that they could write publishable material, while $21 \%$ said they felt they lacked sufficient academic level language proficiency, and $15 \%$ felt they lacked the academic writing skills.

\section{Reflection of participants who did not publish}

The following quotes from some of the participants who did not publish, or published late in the day, demonstrate how a combination of affective factors and the reactions of the outside world, namely those of the publishing outlets, can make or break a prospective novice author.

\section{Participant No 1:}

"I felt anxious, because it was a field that I had never explored before. I sent four emails to different people, only two of them answered." She adds that she has not followed up the activity because she needs to prepare for her classes, has a lot of marking to do, and is exhausted. This participant in due course published a review on a book about teaching in low-resource classrooms (Smith, Padwad \& Bullock, 2017), a topic she felt she could relate to (Matute, 2018).

Participant No 2:

"I remember that I contacted two people. One of them replied rather late. The other one didn't reply. I would like to be contacted by email and would like to write a review. I would be very much interested in doing so."

Participant No 3:

"The editor did not respond immediately, he took a long time and that discouraged me. I did not feel confident enough to ask the teacher trainer."
Participant No 6:

"I sent my proposal and got a response immediately. Two or three days later they offered a book review, but I never got it. I wrote again and they never said anything. I really would like to do it. Given the opportunity, I would do it again."

There might be a number of reasons why the nonpublishers did not persist. Being discouraged and not having the time or energy to follow up initial contacts are possibly among them. The difficulties probably grow exponentially when the manuscript is not a book review, but an article on a piece of research. The problem of lack of time for writing and publishing is echoed by the survey results; we have seen that the main reason for not publishing for $28 \%$ of respondents was that they did not have the time to carry out the research necessary for publishing with one-third adding they did not have the time to write academic texts.

However, Hyland's (2016) proposition that native speakers per se may not be more successful in academic writing than their non-native speaker counterparts seems to be borne out by the fact that neither of the two native English speakers has published (one did not even set aside time to try), and this may have to do with the fact that neither of them has written an MA thesis, which is an intense 'apprenticeship' exercise that those who eventually published (notably, all non-native speakers) had gone through.

\section{Phase 1 of the publishing effort}

Writing for publication is a complicated process starting with the research on which the scholarly article is based. It continues with sending out the text and waiting for acceptance or acceptance with modifications; undoubtedly, the article can be rejected, or a substantial rewrite may be requested. As shown in Table 3, In Phase 1, three of the novice authors' articles were edited and proofread in several rounds before being eventually published. 
Table 3. Summary of the publishing effort in Phase 1

\begin{tabular}{lllll}
\hline Authors & Title & Date published & Genre & Publishing organization \\
\hline Arteaga, M (2017a) & Question of identity & Feb 2017 & Book review & EL Gazette \\
Békés, E (2017a)* & Authentic writing ... & Feb 2017 & Short article & EL Gazette \\
Békés, Carrasco, \& & Writing academically... & Spring Issue 2017 & Research article & TTEd SIG newsletter \\
Jaramillo (2017) & & & & \\
\hline
\end{tabular}

*Written by teacher trainer, not included in the statistics, mentioned only for explanatory purposes

As can be seen in Table 3, the submission and publishing process started soon after the end of the course. The review on Waldron's (2016) book appeared in the February issue of EL Gazette; the trainer added an explanatory note on the authentic academic writing activity to accompany the book review. The article for the TTEd SIG newsletter was the joint effort of three co-authors: Békés, Carrasco, and Jaramillo (2017).

By the end of Phase 1, three of the five participants who eventually published had something to show for their efforts. This is how one of them reflected on the experience:

Writing is not for everyone. As a matter of fact, I thought writing was not for me. The first time I had to write academically was for my MA thesis; I was shocked at the amount of times I had to rewrite paragraphs. ... When I was asked to reach out for publishers and offer to write unsolicited book reviews, I felt on edge, insecure, and to be honest, not really pleased about it, but when I got a reply saying "yes", I could not believe my eyes. Imagine my surprise when I was told this writing assignment was going to be published. I felt proud of myself, I felt like all the effort had finally paid off. (Jaramillo, personal reflection)

Increased self-confidence has been an outcome for all three novice authors, and since lack of confidence appears to be a major obstacle for Ecuadorian teachers, this may be deemed a positive result. Some other contributing factors for this initial success are likely to have been the careful setting up of the activity, its appeal to the participants, substantial preliminary editing work by the trainer, and continuous contact with the editors in the editing / rewriting phase.

\section{Phase 2 of the publishing effort}

This phase lasted from April 2017 to October 2017; Table 4 summarises the publishing outcomes.

Table 4. The results of the publishing effort in Phase 2

\begin{tabular}{|c|c|c|c|c|}
\hline Authors & Title & Date published & Genre & Publishing organization \\
\hline Békés \& Carrasco (2017) & Why NNESTs & Apr 2017 & Book & Academic Study Kit \\
\hline Békés $(2017 \mathrm{c}) *$ & Writing academically... & Spring 2017 & Research article & TexTESOL IV \\
\hline Békés (2017d) & & June 2017 & Blog post & ASK Microblog \\
\hline $\begin{array}{l}\text { Arteaga, Jaramillo, \& } \\
\text { Rodas (2017) }\end{array}$ & Effective Academic... & Aug 2017 & Book review & IATEFL ESP SIG \\
\hline Carrasco (2017) & & Sept 2017 & Blog post & ASK Microblog \\
\hline Arteaga (2017b) & $\begin{array}{l}\text { Integrating global issues } \\
\text { Maley \& Peachey (2017) }\end{array}$ & Oct 2017 & Book review & EFL Magazine \\
\hline
\end{tabular}

Note. Blog posts and the trainer's own article (*) related to the project have not been included in the final count

Phase 2 proved to be a game changer: the trainer and one of the participants wrote a concise book on nonnative English speaker teachers' identity issues (Békés $\&$ Carrasco, 2017). The book was published by Academic Study Kit, the same independent Brightonbased publisher that brought out Waldron's What's Your Teaching Identity? The idea for the book came from the trainer, who had written a review on Waldron's book for EFL Magazine. Békés (2017b) commented:

If having an identity and retaining your innermost core values is difficult for native speaker English teachers, how much more difficult might it be for non-native English teachers? ... Maybe another slim book of The Legacy Series could explore the "whys" of the professional community of non-native speakers who far outnumber NESTs (Native Speaker English Teachers)? (para. 6)

The independent publisher and ELT / ESP expert, Julie Kacmaz, was approached because the prospective authors were aware that she had been supportive of non- native English speaker writers. It was a steep learning curve. The first draft was hastily put together at the end of January 2017. It then transpired that the publisher wanted to launch the book at the IATEFL Glasgow 2017 conference and, therefore, the manuscript had to be finished by the end of February 2017.

Over the next seven weeks, the book was revised comprehensively several times; numerous fine points were raised and resolved with more than 50 e-mail exchanges between the editor and the authors. Both authors found the editing experience hugely educational and appreciated what Hyland (2009) calls "unsolicited language assistance" coming from editors (p. 86). This is how Carrasco reflected on publishing internationally:

I am new to the world of publishing in spite of my many years of experience teaching ESL. ... Many people talk about publishing and getting published as being a real nightmare; a world where you are constantly overcoming rejection. ... I feel that what made our book publishable were two factors: finding the right publishing team and presenting an interesting topic with 
a fresh perspective while being clear about our identity. Publishing internationally made me feel as part of the real world and that my voice and point of view mattered and could be heard in different latitudes. (Carrasco, blog post)

The book was finally launched during IATEFL's annual international conference in Glasgow in April 2017. In August 2017, the collaborative review (Arteaga et al., 2017) on the course book titled Effective Academic Writing (Savage, Mayer, \& Shafiei, 2012) was also published. Each author looked at a different volume of the textbook series that the teachers were going to use with their MA students. Rodas' own words sum up the experience she has gone through:

Last year, I was part of the Academic Writing Workshop, ... I was given the opportunity to participate in a book review "Effective Academic Writing" ... I have to mention this was highly inspiring and motivating because now I am looking for other publishing opportunities. (Rodas, personal reflection)

Phase 2 of the research project was more intensive than Phase 1: three new items were published including a short book, whose size is comparable to that of an average research paper. The two blog posts have not been included in the final statistics, as one was written by the trainer herself, and the genre (blog post) was not considered to be of 'academic' calibre, even though both posts reflected the affective aspects of publishing internationally. One project-related item was written by the trainer (Békés, 2017c), and is mentioned in Table 4 for illustrative purposes. Nevertheless, it is quite possible that the trainer has become a role model in publishing for the participants: she is a proficient nonnative English speaker with a fair number of publications to her name.

The reasons for this heightened productivity could be manifold; they may have arisen from the unrelenting quest for further publishing opportunities, the improved output of the novice writers and the ongoing mentorship provided by the trainer.

\section{Phase 3 of the publishing effort}

As can be seen in Table 5, phase 3 involved publications and related events between November 2017 and the end of April 2018.

Table 5. Publications and projects related to academic writing activities*

\begin{tabular}{lllll}
\hline Authors & Title & Date published & Genre & Publishing organization \\
\hline Arteaga (2018) & $\begin{array}{l}\text { How can technology...? } \\
\text { Meldrum (2017) }\end{array}$ & Jan-Feb 2018 & Webinar review & Voices (IATEFL) \\
$\begin{array}{l}\text { Békés and } \\
\text { Carrasco (2018) } \\
\text { Matute (2018) }\end{array}$ & $\begin{array}{l}\text { International English... } \\
\text { Teaching in low... }\end{array}$ & Feb 2018 & Webinar & IATEFL \\
& $\begin{array}{l}\text { Smith, Padwad, \& } \\
\text { Bullock } \\
(2017)\end{array}$ & & Book review & $\begin{array}{l}\text { TTEd SIG newsletter } \\
\text { Spring Issue 2018 }\end{array}$ \\
& & & & \\
\hline
\end{tabular}

*Present article not included.

Phase 3 started at the beginning of October 2017 and can be perceived as open-ended: one of the participants (Matute, 2018), who did not follow up the leads provided initially, has written a book review for IATEFL's TTEd SIG newsletter on a freely downloadable British Council publication (Smith et al., 2017). Arteaga (2017b) wrote a longer than usual book review for EFL Magazine (see Table 4) and, as a new genre, her webinar review (Arteaga, 2018) was also accepted and published in early 2018. The publication of the present article is further proof that writing can improve dynamically if practised systematically. Arteaga, who wrote the review on the British Council's Integrating Global Issues in the Creative English Language Classroom for EFL Magazine had this to say:

It is said that life is made up of opportunities and this is exactly what happened with the academic writing seminar. A door opened with the workshop, because it was not a workshop to learn how to write an essay with cohesion or a training to use a book. It was a demanding experience where we had to learn to start writing and teaching how to apply what we know to others. (Arteaga, personal reflection)

\section{CONCLUSIONS}

The present research study aimed to establish how tertiary level Ecuadorian teachers attending a training course on academic writing can be encouraged and supported in their efforts to write academically and publish the resulting manuscripts. We found that this can be done successfully as long as the trainer/mentor provides sustained support and the novice authors overcome their 'fear of flying' and start writing.

Taking into account the size of the sample, the results are hard to generalize, but it remains a fact that, over eighteen months, the novice authors, with the active involvement of their more experienced trainer/mentor, managed to publish six modest pieces of writing and a short book (not counting the present paper, the blog posts and the trainer's own, sole-author contributions).

The use of convenience sampling may have affected the generalizability of the study; however, the participants of the training sessions were preselected on the basis of professional credibility and experience. Therefore, they may be more representative of the population that would include all Ecuadorian teachers in tertiary education involved in teaching English for Academic Purposes, namely, language teachers with 
fairly high EAP proficiency levels. The continuation and following through of the publishing effort was only made possible because the trainer carried on supporting and mentoring the novice authors. In the case of a standalone course, lacking continued support, the publishing effort might have fizzled out.

The research also aimed at establishing the success/failure rate of publication. In the end, five out of the nine participants managed to publish at least one piece of authentic academic writing. As mentioned before, two course participants did not get involved in the project (even though one of them later did make a modest contribution to a collaborative book review). Furthermore, there were four participants who, after the first tentative steps, did not pursue any further their writing or publishing effort, but one ultimately wrote a book review. Looking at the results in quantitative terms (even though the size of the sample does not warrant any quantitative analysis), we can see that more than half of the participants wrote and published. However, if one was to appraise the quality and quantity of the output of the five novice authors (one of whom became the co-author of a concise book), the results are probably encouraging.

Nevertheless, a subsequent research project would need to consider further the reasons of those who have 'fallen away'. Time constraints and lack of research and academic writing skills have been mentioned above, but it would be useful to find out what other (psychological and cognitive) factors may be at play to keep Ecuadorian teachers from investing more in their professional development and career advancement by publishing academically.

Since more than eighty percent of the estimated 12 million English teachers worldwide are non-native English speakers, providing academic literacy support within the framework of English for Professional Academic Purposes (EPAP) can be highly recommended so that the millions of would-be scholars could obtain access more easily and gain presence in the global 'knowledge economy'.

Authentic academic writing activities in an EFL context may not be easy to set up, but they have definite rewards, such as providing an opportunity to learn by doing, gaining professional acknowledgement and entering the competitive arena of international publishing. The majority of Ecuadorian teachers do not have sufficient academic writing skills and also lack the self-confidence required to publish. This calls for further research on identifying the reasons why Ecuadorian teachers perform poorly in this area. Furthermore, special attention would need to be paid and more research should be conducted into the emotive aspects of (academic) writing, particularly in an EFL context.

\section{ACKNOWLEDGEMENTS}

We would like to acknowledge the logistical and moral support that we received from the Catholic University of
Cuenca, Ecuador that organized the original training course. Our special thanks go to all the editors and publishers who have worked with us in each and every stage of the academic writing and publishing project. The authors received no financial support for the research, authorship, and/or publication of this article.

\section{REFERENCES}

Arteaga, M. (2017a, February). Question of Identity [Review of the book What's Your Teaching identity?, by H. Waldron] EL Gazette, p. 15.

Arteaga, M. (2017b, October 9). Integrating Global Issues in the Creative English Language Classroom [Review of the book Integrating Global Issues in the Creative English Language Classroom: With Reference to The United Nations sustainable development goals, by A. Maley \& N. Peachey (Eds.)]. EFL Magazine.

Arteaga, M. (2018). IATEFL Webinar review [Review of the webinar How can technology support and facilitate teacher led development?, by $\mathrm{N}$. Meldrum]. IATEFL Voices, January-February 2018, Issue 260, p. 24.

Arteaga, M., Jaramillo, D., \& Rodas, T. (2017, July). [Review of the series Effective academic writing, by Savage, A., Shafiei, M., Mayer, P., Liss. R., \& Davis, J.] Journal of the IATEFL ESP SIG, 49, 6263.

Békés, E. (2016, October 21). A-Z of intercultural communication [Review of the book $A-Z$ of intercultural communication, by E. Camerer \& J. Mader] EFL Magazine. Retrieved from http://www.eflmagazine.com /book-review-zintercultural-communication/

Békés, E. (2017a, February). Authentic writing task. EL Gazette, p. 15. Retrieved from: http://www.textesoliv.org/wpcontent/uploads/2017/04/WritingAcademically_ErzsebetBekes_Spring_2017_33112.pdf

Békés, E. (2017b). What's your teaching identity? [Review of the book What's your teaching identity?, by $\mathrm{H}$. Waldron]. EFL Magazine. Retrieved from http://www.eflmagazine.com /whats-your-teaching-identity/

Békés, E. (2017c). Writing academically: Accomplishing an authentic task by Ecuadorian teachers in an EFL setting. TexTESOL IV, Fourth Estate, Spring 33(1), 36-37.

Békés, E. (2017d, June 13). Changemakers 3 NNESTs get published: Is there fairness and equity in the EFL world? [ASK microblog].

Békés, E., \& Carrasco, M. (2017). Why NNESTs? International English and its implications for teacher development. Brighton, England: Academic Study Kit.

Békés, E., \& Carrasco, M. (2018, February 3). International English and its implications for teaching and learning [Webinar]. In 
IATEFL Webinar Series. Note: available only to IATEFL members.

Békés, E., Carrasco, M., \& Jaramillo, D. (2017).

Writing academically: Accomplishing an authentic task by Ecuadorian teachers in an EFL setting. IATEFL Teacher Training and Education SIG Newsletter, Spring 2017, 10-14. Retrieved from http://edition.pagesuiteprofessional.co.uk/Launch.aspx?EID=0afca545663e-48e6-a7eb-9b425bb5d615

Bourdieu, P., \& Passeron, J-C. (1994). Introduction: Language and relationship to language in the teaching situation. (R. Teese, Trans.) In P. Bourdieu, J-C. Passeron \& M. Saint Martin (Eds.), Academic discourse: Linguistic misunderstanding and professorial power (pp. 1-34). Stanford, CA: Stanford University Press.

Buckingham, L. (2008). Development of English academic writing competence by Turkish scholars. International Journal of Doctoral Studies, 3, 1-18. doi: $10.28945 / 47$

Carrasco, M. (2017, September 5). NNESTs publishing abroad. [ASK microblog].

Gillett, A. J. (2011). What is EAP? Retrieved from http://www.uefap.com/bgnd/eap.htm

Gilmore, A. (2007). Authentic materials and authenticity in foreign language learning. Language Teaching, 40(2) 97-118. doi: $10.1017 / \mathrm{s} 0261444807004144$

Hyland, K. (2009). English for professional academic purposes: Writing for scholarly publication. In D. Belcher (Ed.), Teaching language purposefully: English for specific purposes in theory and practice (pp. 83-105). Ann Arbor, MI: Michigan University Press.

Hyland, K. (2016). Academic publishing and the myth of linguistic injustice. Journal of Second Language Writing, 31, 58-69. doi: 10.1016/j.jslw.2016.01.005

Kachru, B. B. (1985). Standards, codification and sociolinguistic realism: The English language in the outer circle. In R. Quirk \& H. G. Widdowson (Eds.), English in the world: Teaching and learning the language and literatures (pp. 11-30). Cambridge, England: Cambridge University Press.

Lidvall, C. D. (2008). Get real: Instructional implications for authentic writing activities. Retrieved from (Vanderbilt University, Discover Archive) https://discoverarchive. vanderbilt.edu/bitstream/ha ndle/1803/789 /CarlyLidvallCapstone.pdf
Lindblom, K. (2015, July 27). School Writing Vs. Authentic Writing. Retrieved from https://writerswhocare.wordpress.com/2015 /07/27/school-writing-vs-authentic-writing/

Maley, A., \& Peachey, N. (Eds.). (2017). Integrating global issues in the creative English language classroom: With reference to the United Nations Sustainable Development Goals. London, UK: British Council.

Matute, H. (2018). Book Review: Teaching in lowresource classrooms: voices of experience [Review of the book Teaching in low-resource classrooms: voices of experience, R. Smith, A. Padwad, \& D. Bullock (Eds.)] IATEFL Teacher Training and Education SIG newsletter, SPRING 2018, p. 18. Retrieved from http://edition.pagesuiteprofessional.co.uk/html5/reader/production/default .aspx ?pubname $=\&$ edid $=4 \mathrm{a} 251208-4702-47 \mathrm{c} 1-$ 86c2-ef3b0788c76a

Ozverir, I., Herrington, J., \& Osam, U. V. (2016). Design principles for authentic learning of English as a foreign language. British Journal of Educational Technology, 47(3), 484-493. doi:10.1111/bjet.12449

Pinner, R. S. (2016). Reconceptualising authenticity for English as a global language. Bristol, England: Multilingual Matters.

Renandya, W. A. (2014). Choosing the right international Journal in TESOL and Applied Linguistics. ELTWorldOnline.com, 6. Retrieved from http://blog.nus.edu.sg/eltwo/files/2014/06/Choosin g-the-Right-International-Journal-in-TESOL-andApplied-Linguistics_editforpdf-10fy3c2.pdf

Savage, A. (2012a). Effective academic writing: Introductory: Student Book (2nd edn.). Oxford, England: Oxford University Press.

Savage, A. (2012b). Effective academic writing 3: Student Book. Oxford, England: Oxford University Press.

Savage, A., \& Mayer, P. (2012). Effective academic writing 2: Student Book (2nd edn.). Oxford, England: Oxford University Press.

Savage, A., \& Shafiei, M. (2012). Effective academic writing 1: Student Book (2nd edn.). Oxford, England: Oxford University Press.

Smith, R., Padwad, A., \& Bullock, D. (2017). Teaching in low-resource classrooms: Voices of experience. London, England: British Council.

Waldron, H. (2016). What's your teaching identity? Brighton, England: Academic Study Kit. 